\title{
The Influence of Barbizon School's Educational Approach on Modern Art and Nature-Art Relationship in Jackson Pollock Works
}

\author{
Hasan Zeybek ${ }^{1 *}$, Uğurcan Akyüz ${ }^{1}$ \\ ${ }^{1}$ Near East University, N. CYPRUS
}

Received 9 June 2017 • Revised 31 August 2017 • Accepted 7 October 2017

\begin{abstract}
This study evaluates the factors forming Modern Art by examining the Barbizon school's approach in art education, in comparison to the academic understanding of art. The invention of photography steered the visual art schools towards a new conceptualization of nature. The awareness that Impressionist and Post-impressionist movements achieved in the depiction of nature came to define modern art. Modern art finds character with the learning outcomes of new art education and approaches that brake away from the traditional Renaissance depiction of nature. Cubist movement which forms a foundation for Modern art transformed the images of nature through a conceptual perception that experiences visual reality as a mental stage. The impact of Cubist geometric and multi-perspective portrayal of nature will be examined in Modern Art painting samples. The artistic performance of Jackson Pollock will be associated with the development of Modern Art to provide a fresh perspective on art-nature relationship.
\end{abstract}

Keywords: Barbizon school, cubism, impressionism, modern art, nature, performance

\section{INTRODUCTION}

The depiction of nature in art is a compelling subject that necessitates the study of various movements; schools and artists with their respect in developments to their emergence, treatment and perspective on nature and art. The relationship of art and nature does not consist of a monolithic definition. The process of depicting nature in art is outlined and milestones of this evolution are described.

This study is also an attempt to inquire into the ever-changing relationship between the artists, the surrounding environment and nature. This relationship is firstly analysed in relation to the elements of belonging and existence in art. The factors that produce images of nature found in modern art and its ties to Barbizon School's artistic education and the discipline it had shaped through the attitude towards nature. The effects of invention of photography, as a form of documentation, together with the teachings of Barbizon school help shape the movement of Impressionism, which evolved to treat nature while prioritizing given to artist's identity and subjectivity. In the aftermath, the effect of Postimpressionism on Modern Art and Cubism, which conceptualizes nature through geometric formations, is looked at. Lastly, the crux of modern art with nature is studied through the performance of Jackson Pollock whose works suggest a new understanding of the relationship between art, nature and artist. The study of this evolution of treatment of nature and its relationship to art and the artist provides a precept to people studying art.

\section{METHODOLOGY}

This study is a comparative analysis of artists and movements that shaped attitudes and approaches in the development of modern art. The works, artists and movement analysed are representatives of the attitude in art towards nature and significance of these attitudes with respect to art education. 


\section{Contribution of this paper to the literature}

- This paper contributes to the studies of the ever-changing artistic understanding of the ever-changing artistic understanding and artistic education in relation to depiction of nature.

- The evaluation of the changes in artistic approaches from Barbizon school that led to the foundation of Modern art.

- The assessment of the role that subjectivity as an element of Modern Art played in creating a new perspective of nature in art.

The depiction of nature in the works of artists and movements stemming from Barbizon School, Impressionism, Post-Impressionism, Cubism to J. Pollock are compared in an eclectic perspective that defines treatment of nature.

Artistic attitudes and approaches in the era of modern art does not consist of a monolithic description nor depiction in content, context of production and process of artistic creation; visual, stylistics, technical aspects and materials. These identified variables also define the significance of these works and approaches in respect to depiction of nature and portray.

\section{LITERATURE REVIEW}

\section{A General Review of Artist - Nature Relationship, Artistic Expression Process in Modern Art through the Lens of Art History}

Human beings develop a sense of belonging to the space and environment in which they exist; starting from birth and continuing for lifetime. The climate, geographic conditions and the socio-economic conditions help to shape life styles and cultures which all play an important role in the development of communal and individual identity. The artist's individual sense of belonging that develop in relation to the communal lifestyle and identity in which it exists are projected in artists' works in one form or another.

In general terms, art is accepted as a form of expression and artistic production actualised in different contexts and for various purposes; in the period dating from communal life to today's society. The view of art as expression attributes a role to artistic production. Artistic production as an act of expression suggests a continuous urge, which lasts through the transformations and revolutions; from the invention of the wheel or paintings on the walls of the cave.

In this respect, we must note that the action of painting initially requires the use of lines, colours and dyes. The person expressing himself/herself on the cave walls draws the conceptual image in his/her mind, i.e. image of a bull with dyes. There are no contour lines in the physical presence and volumes in nature. In Onthology of Art, Ismail Tunalı examines these different existential layers (Tunal1, 2002, s.117). The idea of existence mentioned has fundamental differences between the bull that exist in nature and the bull portrayed in the paintings. At this point the painter paints the bull with the use of lines on the wall of the cave. The conceptual image of the object (the bull) in mind is depicted with the use of lines, which are human-specific expression tools, and the produced image embodies artist's own existence and identity. The painted image of the bull is the product of the inner conceptualization of the external world. This perspective coincides with a similar conception of art in the movement of Cubism since art is accepted as a conceptualization of the external world. The bull is perceived as a product of artist's existence and identity and the process of producing a representation inevitably carries the feelings and thoughts of the artist.

The understanding of modern art constitutes a period of interrogation in the history of art characterized by detachment from traditional artistic thought and approaches. This characteristic makes modern art highly mobile and rapidly evolving as it incorporates the current avant-garde ecoles, movements and groups.

Modern society from a sociological point, humans have had major transformation with respect to the social structure from the communal life through the agrarian revolution. As people became accustomed to life in earthrelated conditions for thousands of years was transformed through the industrial revolution, which brought about the psyche where humans are the actors. These revolutions and developments shaped the world, way of life of the society, and the definition of what it means to live on earth. These revolutions also increased the demand for financial markets, raw materials and labour that was created by industrialism. The demands were met through colonization in order to fuel the market economy. Resistance to colonization and its conditions inevitably led to the establishment of nation that marks the process of disintegration of empires and conflicts that it brought that are marked with the first and second world wars. Of course the overt summary of human history given has far reaching consequences for people, societies and the world. The conditions of the period are analysed in Larry Shiner's book Invention of Art, (Shiner, 2001, s.330). The shifts and changes in human history also has its repercussions art and 


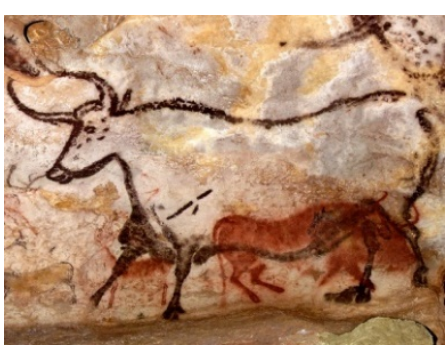

Figure 1. Anonymous, Bison, Sprayed Root Paint on Rock, BC 30.000 Lascaux Cave, France. 30000 years of art: the story of human creativity across time and space AC06420622, A. (Ed.). (2007). 30000 years of art: the story of human creativity across time and space. Phaidon.

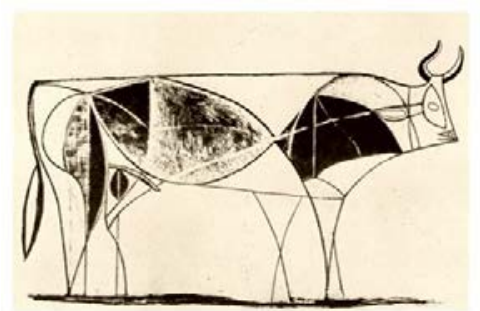

Figure 2. Pablo Picasso, The Bull, Lithograpy, $30 \times 50 \mathrm{~cm}$. Walther, I. F. (2000). Picasso. Taschen

this is exemplified with the effects of technological changes on art in Qin Jia, Zhao Keheng and Yu Haiyang (2017) as,

"Technology is the accumulation of human competence to learn and understand the physical world. This well explains the phenomenon mentioned in the previous paragraph that as a result of the continuous changes in art forms due to the development of society, the form and contents of arts are constantly challenging and reforming the previous definitions." (Jia, Keheng, Haiyang, 2017)

These events also influenced art and the artist. Artists' belonging has been directly influenced by the transformations of people and society due to the reflective quality of the work of art. The results of shifts and changes in history has evolved modern society in various respects including social, political, economic, and scientific such as its application in ground breaking technological elements.

On the other hand, historical process that led to modern society is interwoven with the cross fertilization of effects in art. Modern Art is characterised with a deviation from reflection of natural imagery and detaches itself from naturalism. The abandonment of naturalism signals the abandonment of a long deep-rooted tradition of artistic perception that has been in accordance with the first known paintings of human history, which are the cave paintings. This crux produced an intellectual awareness of cave paintings aesthetically and intellectually is what found substance in modern art. The common ground in the pure aesthetic attitude in the depiction of the bull in the cave and the conceptualized stylized version by Picasso is characterized by their aesthetic attitude of same volume and depth that could be observed in Figure 1 and Figure 2.

\section{FINDINGS}

\section{Barbizon School's Art Education and Conditions that Create Modern Art}

The changes in economic, technological and environmental factors also helped to reshape the understanding of art education of. In other words, social developments are accompanied by changes in art, as the mirror of the society, and art education.

In his book Sociology of Art, Soykan identifies the sociological aspects of art by stating "Works of art reflects the emotions and ideas of societies of a given time and space." (Soykan, 2009, p.16)

The emergence of Nation states after the French Revolution and the social transformation of Industrial Revolution correlate directly with the changes in the approach to art education. For instance, Barbizon School is a good example as to how new methodologies and techniques were employed in depicting nature and every-day life. 


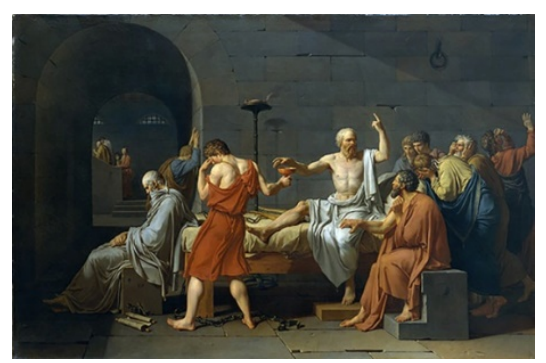

Figure 3. Jacgues-Louis David, The Dead Of Socrates, Oil on canvas, $129.5 X 196.2 \mathrm{~cm}$, The Metropolitan Museums Of Art, New York, Galitz, K. C. (2016). The Metropolitan Museum of Art: Masterpiece Paintings. Metropolitan Museum of Art.

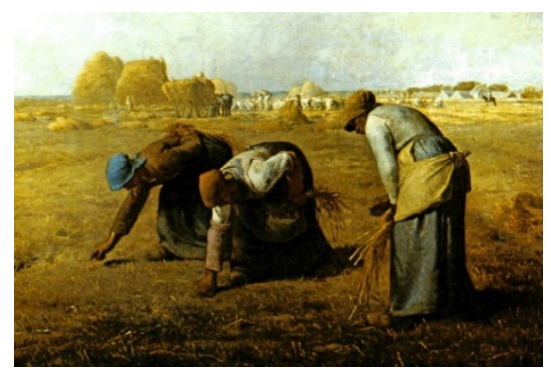

Figure 4. Jean-François Millet, The Gleaners, Oil on canvas 1857,83.5x111cm, Musee D.Orsay,Paris. Gombrich, E. H., \& Gombrich, E. H. (1995). The story of art (Vol. 12). London: Phaidon

Barbizon school's educational approach develops between 1830's until 1870's. The pioneers of this society are mainly John Constable, Jean-François Mille, Jean-Baptiste Camille Corot and Theodore Rousseau. This circle of artists was exempted from the French academic style of painting and workspace and they developed a new approach where nature is depicted, they painted out in open air by using natural sunlight. Louis David, who is one of the pioneers of French Academic Painting, was emphasizing the daintiness of drawing from a real-live model and hated improvisation and disarray (Gombrich, 1995, p.504). The academic style painting that depicts the 'Death of Socrates' by Louis David (Figure 3) was fictionalised in a studio and incorporated a classical composition that adopted a classic understanding of aesthetics.

Contrary to the Academic tradition, Barbizon school appropriates a naturalist and realist approach in depicting nature. In The Story of Art E.H. Gombrich mentions Francois Millet's The Gleaners (Figure 4) by noting that what is depicted is neither a dramatic situation nor a story but only three women harvesting a field (Gombrich,1995, p.508). Unlike the academic art education, Barbizon School portrays everyday social events and worldly affairs. Artists of Barbizon school develop a realist approach in depicting nature and portray of events as a reflection of reality. Though the artists would incorporate an individual approach to the subjects, there is a strong commitment to the imagery of nature. For this, Barbizon school is considered as the starting point of the realist movement. The Barbizon school advocated painting in nature by giving primary importance to surrounding environment. The school strived to portray worldly images of ordinary daily life and not of religious, political or mythological topics of art history. During the middle ages, mythological themes dating from antiquity had the mission of transferring religious themes and topics to audiences in line with the definition of Peter Burke's The Renaissance,(Burke, 1969) The period of Renaissance trying to uphold ideal beauty and ideal principles favoured a perspective formulated with geometrical shapes to Baroque's artistic rationality and ratio and proportion favouring more emotional outcomes.

Roccoco movement exemplifies the overarching expression of Baroque in which Neo Classicism is downgraded to its rationality and an ideal ratio and proportion. Barbizon school shared the period with Orientalism that could be accepted as a vision of colonialism, which was an enterprise that controlled continents outside of Europe. The movement of Orientalism also portrays similarity with the Barbizon schools since it incorporates exoticized natural images and scenery and people as other. Although depiction of the other incorporates a sociological sphere, we are referring to the style and imagery of Orientalism.

Painting in natural setting reinforced the astonishment towards the surrounding nature and the self who inhabits it. In the foreword of 'La naissance de l'individu dans l'art, Henri Tavoillot notes that works of art slowly moves away from the divine into depicting this world's daily life, universe of emotions and humanly mannerisms in a unique way. This preferred approach that Barbizon School would lead to the emergence of subjectivity and individuality as the main subject of the works of modern art which in turn would lead to the expressive performance of Jackson Pollock. (Legros,L Foccroulle.B Todorov.T, 2005, p.7) This plateau governed with the 
artistic ideals and academies of the period inevitably led to the establishment of alternative works of art that were not exhibited in the hall exhibitions of the period. Impressionists made their way into the art world by creating alternative paintings shaped by problematic issues. Barbizon School that developed a new way of expression as an alternative to the academic art understanding, directly influenced Impressionism.

Yet, beyond Barbizon School, the invention of photography is a greater influence for Impressionist movement to emerge. The invention of photography is one of the elements that create divergence from traditional attitudes and lead to the emergence of Modern Art. The invention of photography by Nicephore Niepce in the years of 182627 lead to a wide-spread phenomenon that shattered various dominant artistic understandings of the period. The invention of photography ended the era of royal portraits being the single form of documentation, which was only afforded, by the ruling class and monarchy as an elitist tradition. (Turani, 1992, p.508)

The effect of popularisation of photography, it set in motion major shifts for the life styles and artistic values of artists. The period of changes created an urge for the redefinition, re-evaluation of art, its importance, its roots and its purpose.

The success of photography in documentation led artists to diverge from conveying the unobtainable aspects, which photography could not convey. This movement created a unique critical inquiry for a new style and school in philosophical and ontological terms. Art shifted from studios being in nature. Nature was at the foreground of the art work and is exemplified in Barbizon school. Impressionism and Post-Impressionist movements are the initial products of this inquiry. Françoise Heilbrun's study Impressionism and Photography suggests that the effects of photography and naturalism have been forces in shaping Impressionism; "Photography unquestionably contributed to the making of some impressionist paintings, but as catalytic agent, and the influence was short lived as the naturalistic vein in all the painters, from Monet to Renoir who moved into a very different direction." (Heilbrun, 2009)

The naturalistic flow felt in the impressionistic painting also cross fertilized the modern art's treatment of nature. In an interview on the effects of photography on art, pioneer of Cubism Pablo Picasso expresses his perspective towards photography as:

"When you see what you express through photography, you realize all the things that can no longer
be the objective of painting. Why should the artist persist in treating subjects that can be established
so clearly with the lens of a camera? It would be absurd, wouldn't it? Photography has arrived at a
point where it is capable of liberating painting from all literature, from the anecdote, and even from the
subject. In any case, a certain aspect of the subject now belongs to the domain of photography. So
shouldn't painters profit from their newly acquired liberty, and make use of it to do other things?"
(Ashton, 1988, p.109)

Picasso's statement pinpoints the inquiry of modern art with respect to naturalism.

Impressionism established itself in 1860s France, it also began to be accepted in art circles around Europe (Cunningham, 2000.) Impressionism is highly committed to the naturalist painting tradition but with an alternative sensitivity to form of being and artistic vision. The essence of the treatment of Naturalism in Impressionism can be described not in a sense of nature independent humans but it is rather an artistic understanding that sees the reality of nature through human emotions and subjectivity.

The point of divergence mentioned here gave rise to the formation of Modern Art. İsmail Tunalı expresses impressionist perspective towards naturalism and the conditions it produced due to the invention of photography as, "Impressionist do not view or regard nature simply as a naturalist; if that had been the case then he would be nothing more than a camera." (Tunal1, 2003, p.6) Impressionism grasps nature through a new perspective but the impressionist painting does not act independently of the objects in the nature. Ismail Tunali uses the following expressions on the understanding of reality in Monet's paintings whose works are accepted as one of the most important representatives of the Impressionist Movement:

"When we look at Monet's world of objects, there is a reality, a non-existent one, everything that
attaches to the object of the conversation and gets solved as a sensation, an impression complex. When
Monet looks at nature in that sense, he sees the flow of colour and light, the flow of impressions that
are reality, not reality itself, and the bond between object and object is established through Impression
directly." (Tunal, 2003, p.41).

In the conceptual framework of Impressionist images of nature, objects are depicted as the realty seen, comprehended and interpreted. In this understanding, senses are primary; the elements of mental reason such as shape, volume, mass, depth, perspective, etc., are all left behind, leaving the three-dimensional illusion of painting on a two-dimensional flat surface. The study of Impressionist artist Monet's painting (Figure 5) suggests that forms and lines are applied in layers in the direction of the impression and dissolve to create the picture. 


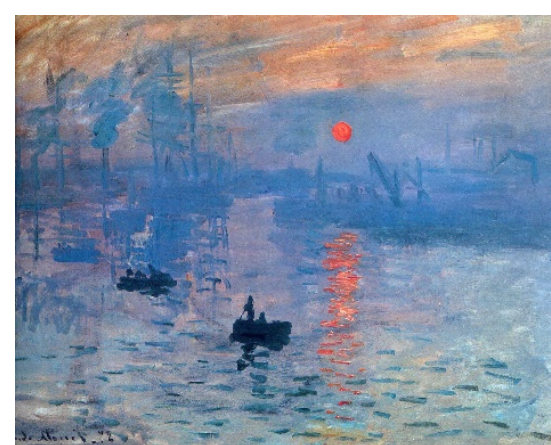

Figure 5. Cladue Monet, Impression Sunrise, Oil on canvas, 48x63cm Musee Marmottan Paris. Sagner-Düchting, K., \& Monet, C. (1990). Claude Monet: 1840-1926; ein Fest für die Augen. Bertelsmann-Club.

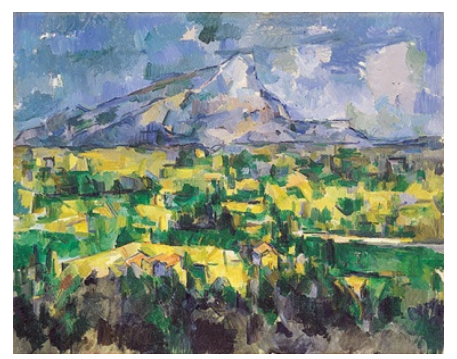

Figure 6. Paul Cezanne, Mont Sainte-Victorire From Les Lauves,Oil on canvas, 60x72cm Basel,Öffentliche Kunstmuseums.Basel. Gombrich, E. H., \& Gombrich, E. H. (1995). The story of art (Vol. 12). London: Phaidon

Impressionism examines the projections of objects and their effects on one another at various moments of the day provides an understanding of painting based on subjective senses that photography cannot obtain.

In this respect, it diverged from the traditional way of depiction to expose a new adventurous terrain in which the artist's priority in the work became inner conceptualization and subjective existence. This changed the perspective of process of art and artistic expression in various ways; subjectivity became primary alongside with the positioning of the individuality of the artist, definition of the artist changing from what they do to who they are, with respect to subjective existence. This approach causes the artistic expression to leaves behind thematic and aesthetic values and shifts the importance in expression of subjectivity.

The features of impressionist painting and the artistic experiences associated with it signalled a new context which can be exemplified with post-impressionist artist Paul Cézanne whose works portray the shifting nature of art towards the Cubist movement. Paul Cézanne; brought a new approach to impressionist perception of nature in which the artist's feelings and senses are illustrated through the use of colours that fuse together the components of mass, volume, depth and lines through its artistic treatment of geometric forms in still life. This artistic expression reduces the image of nature to geometric principles. Cézanne aims to create a permanent structure that is independent from the impressions of objects that will not change according to sensations of nature. Sensations are approached with geometric insight. The impressionist inquiry brings a new definition and perspective to the impressionist movement. Cézanne's questioning of Impressionism brings a new perspective and a new definition. In this respect, Gombrich defines Cézanne as the father of Modern Art. (Gombrich, 1995, p.543)

In the letter sent by Cezanne to Emille Bernard' Aixen Provence, on 15th April 1904 he writes "Take nature as a cylinder, cone or globe and place the line in a perspective that all the surfaces of the object brings you to the cylinder." (Tunal1, 2003, p.123). The letter addresses the path that cubism took in Cezanne's paintings. The geometric nature conception and the use of multiple perspectives makes Cezanne question the tradition of imaginary vanishing point on a single horizontal line.

The painting surface is studied from many different perspectives which are shown to the viewer at a single glance (Figure 6 and 7). This experience is a vital awareness for the formation of the Cubism movement. Cezanne uses multi perspective in the face of nature's reality. Cezanne's approach liberates the artist from depicting nature through a single perspective. 


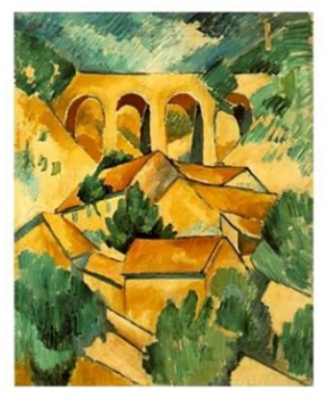

Figure 7. Georges Brague, Viaduct at Lestague,oil on canvas,72x59 Musee D art Moderne Paris. Becks-Malorny, U., \& Cézanne, P. (2007). Paul Cézanne: 1839-1906; Wegbereiter der Moderne. Taschen.

In Cezanne's artistic expression, if the reality in nature is handled by reduction to geometric shapes, nature is depicted by 'self-shaping' through a perception that is conceptualized by thought and mind, not by sensual and apparent shape. The artist's assertion of self on nature implies that he embodied himself in the object by mimicking nature's image.

\section{Modern Art and the Detachment from Natural Images}

The Cubism Movement influenced by postimpressionist understanding of Cezanne starts to deduce nature to geometry and reverses its portrayal and portrays nature through a geometric essence. The fact that Cubism portrays nature through geometry suggests that nature's image in the movement is not a simple representation but a conceptual one. In Cubic painting, the laws of nature, which are now inextricably used, are completely removed, and the masses and forms of the objects are painted with many different points of view are presented on a single canvas surface. In this respect, Cubism finds an identity by cutting its ties with Naturalism that had been continuing since Renaissance.

Renaissance paintings are usually designed as one point perspective stages. Erwin Panofsky defines the perspective in Renaissance paintings as a window that opens before the viewer inviting them to see what is beyond as a real image. (Panofsky, 1991, p.10)

Cubism, contrary to this 'painting as a window' approach, brings a multi-perspective approach with subjects seen in different ways where the perspective of the artist becomes more dominant over nature.

In this context, Cubism finds identity by completely cutting off its ties with naturalism. A lot of schools and trends in the field of modern art have been directed to many different media on the basis of this experience and modern art has been a period of expressing a highly variable variety with this feature. Pollock expresses this direction of Modern Art in the form of water;

\footnotetext{
"The modern artist is living in a mechanical age and we have a mechanical means of representing objects in nature such as the camera and photograph. The modern artist, it seems to me, is working and expressing an inner world - in other words - expressing the energy, the motion, and other inner forces." (Harrison, Wood, 1992, p.576)
}

With Cubism, Art is no longer an imitation nor an imitation of nature that reflects real-emotional order. The still life we have seen in cubism is no longer given to us in a single perspective. The fruits in a picture depicted in cubic understanding are not natural fruits but intellectual abstract elements that are geometric. Pablo Picasso, influenced by the Post-Impressionist Paul Cézanne uses a multi-perspective angle with the mass and volume of the figures, reducing those to geometric shapes in 'The girls of Avignon'. 


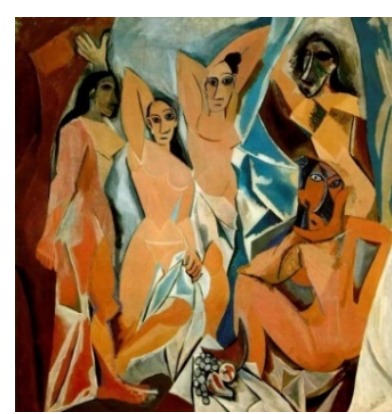

Figure 8. Pablo Picasso, The Girls of Avignon, oil on canvas,243.9x233.7 cm Museums Of Modern Art, New York. Lynton, N. (1980). The story of modern art.

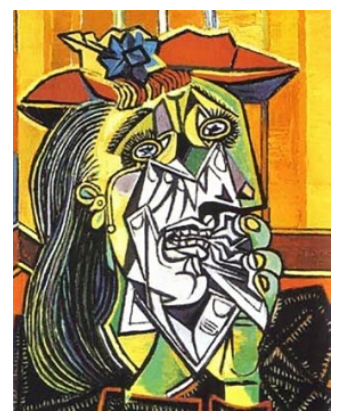

Figure 9. Pablo Pıcasso, Weaping woman,oil on canvas, 60x49cm. Penroze Collection London. Walther, I. F. (2000). Picasso. Taschen.

Norbert Lynton, in his book titled, The Story of Modern Art, explores the relationship between Picasso's The girls of Avignon and paintings of Cézanne. (Lynton, 1980, s.54) The painting comes to be regarded as the manifesto of Cubism.

"They should put out the eyes of painters, as they do to goldfinches to make them sing better." (Berger, 2011, p.32) Picasso's metaphoric judgment is crucial in expressing that the image and the subject are inward projections rather than external ones, i.e., the images and senses of the outside world, and their impression. Picasso embodies his artistic expression as a painter, but expresses the origin of his artistic expression as his inner sensation.

Conceptualisation and inner reality-based perception of the artist against nature suggests a crack with the nature and turns the artist into the single central point of expression as 'pure being'. The artistic content of Jackson Pollock's painting performance is considered in this context. This point also forms the founding element of Pollock's work as he expresses that he himself is the topic of his work. In a meeting with William Wright (1912-1956), Pollock said

"The thing that interests me is that today painters do not have to go to a subject matter outside of themselves." (Harrison, Wood, 1992, p.575). This relationship is dealt with in more detail through Pollock's performance process later on in the study.

While nature and objects are being depicted, they are transferred to the painting surface, which is a twodimensional work area, through materials and elements such as paint, line, and stain. The creation of illusions such as the existence of mass and volume in earth is an indispensable method of artistic understanding that is used ever since the Renaissance to Modern art. The nature and objects are applied to a two-dimensional surface with geometrical elements, which produce a perspective of depth and the illusion of three dimensions.

The fact that nature cannot be naturally presented on the painting surface since it is presented onto a surface through human conception and perception where nature is reduced into lines and geometric structures. Therefore, art can be described as a conceptual activity which is essentially an entity from human senses and human mind.

Modernism takes this process as a foundation for its productions of interiorized expressions with the use of only colours, painting, form, and expression. The natural reality of the images and the theme are completely excluded by being rendered into the side element. In a sense, the understanding of modern art has left behind the aesthetic and semantic mission of art by grasping art through its own roots.

There is a major similarity between Modern art and the early artists who painted the conceptualized bull on the walls of the cave, despite sociologic and technologic differences. The modern artist and the early artist both depict the interiorized conception in a basic form and give substance to the products of astonishment of their existence. In its origins, art as a product of the artist which perceives and conceives the nature and expressed himself/herself 
through non-existent elements of nature which brings us natural images as a transformation of identity and individuality. Art becomes a confrontation in which the artist's individual identity and personality manifest itself onto nature and work. At this point, the painter who perceives nature has pictured himself in the picture, which he has performed with his own hand over the image he used and watched himself when he painted. This experience of the art of painting makes it possible for the object to be portrayed in indivisible contexts because of its nature in cubism, there by positioning the picture as completely disconnected from the manifestations of nature. Picasso comments on the realist relationship between nature and art as; "They speak of naturalism in opposition to modern painting. I would like to know if anyone has ever seen a natural work of art. Nature and art, being two different things, cannot be the same thing. Through art we express our conception of what nature is not." (Aston, 1988, s.4)

The point that Picasso raises on the relationship of art and nature is both valid for modern art and the image, and the reality of nature. This perspective positions the existence of the artist and identity into the existence of the work as two separate forms. In Picasso's understanding the artist and his/her conceptualisation in between the visual of the work of art and the images of nature.

In this research, the impression and nature initially puts forth the subjective impressions in paintings, but this process led to the disconnection of naturalist reality of nature. Grasping nature through a conceptual basis of images is the essence of Cubist movement. The individual preferences of the painter become the main theme that separates the aesthetic and theoretical dimensions of the painting.

The adventure of the artistic subjectivity and absolute existence of the artist, in painting continues with the experiences of Jackson Pollock. He reached a point where the image of nature is completely extinguished.

At the same time, Pollock removes the traditional method of painting from its operative origin and positioned the artist who has established a totally new type of relationship with nature. For the artist who has a special relationship with nature and belonging, he transforms the painting process into performance of dance and trance. The integration of the artist with pure existence and nature creates an unconscious state.

Works of art inevitably incorporate a ritual due to the operation of its creation. For the first time this ritual tradition is questioned as solely a ritual. William Wright asked Pollock a question about this,

"Would it be true to say that the artist is painting from the unconscious, and the - canvas must act as the unconscious of the person mho views it? JP: The unconscious is a very important side of modern art and I think the unconscious drives do mean a lot in looking at paintings." (Harrison EWood, 1992, p.575)

As a result of the painting that emerged through performance of Pollock, it becomes an unessential element and the painting process becomes a special expression as Pollock's art. The paint that are poured with Pollock's performance are in a sense, the pure traces of Pollock's existence. In this respect, painting is an evidence of reflection and documentation of the existence of the painter. The state of pure existence and nature merging and becomes a kind of trance.

In the traditional context, since art inherently possesses trance and ritualism suggests that every work inherits its operative roots through the process of its production by the artist's ingenuity and technical attempt. However, for the first time in the context of art history, besides its message and theoretical contexts, the images of nature and the inspiration from nature, all emerge in the picture of Pollock which is regarded as the art form of action painting.

In the process of artistic expression based on performance, Pollock brings a revolutionary innovation to the origin of the work of art through the experience of completely abandoning all painting traditional habits from Modern Art. Pollock used water as a reference to William Write when he described his work; "The paint I use is usually liquid, fluid type paint. The brush I use is not used as a brush but as a stick. The brush does not touch the canvas but travels over it" (Harrison \& Wood, 1992, p.625) Figure 10, Photo of Pollock working in his studio in line with his statement. In another statement Pollock; 


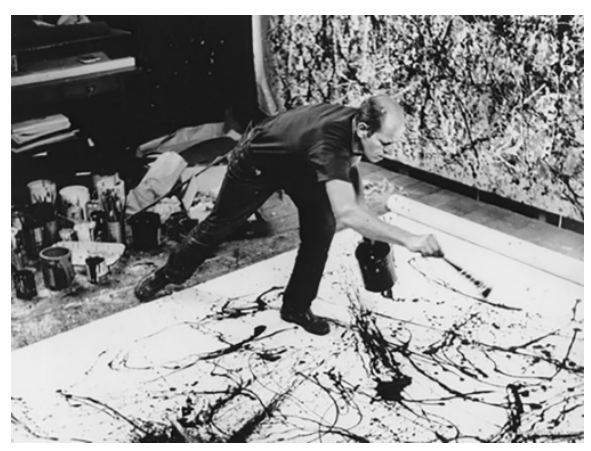

Figure 10. Jackson Pollock, Pollock working in his studio,20.09.2017 http://terraingallery.org/art-criticism/jackson-pollock-andtrue-false-ambition-the-urgent-difference/

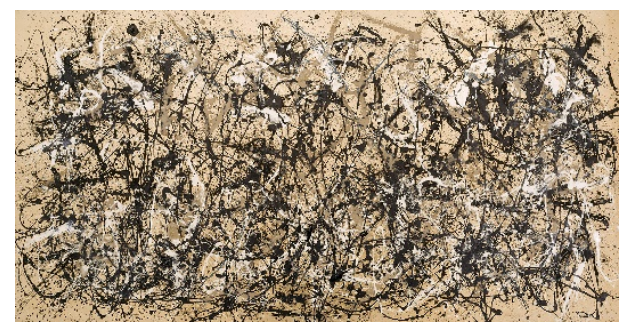

Figure 11. Jackson Pollock, Number 30, Oil on canvas $269.5 \times 530.8 \mathrm{~cm}$ Modern Art Museums of New York. Gombrich, E. H., \& Gombrich, E. H. (1995). The story of art (Vol. 12). London: Phaidon

\begin{abstract}
"Easel, palette, brush, etc., I'm moving away from the usual painting tools and I'm tempted to work with sticks, drops, blades and dripping liquid paint or use sand with broken glass or other stuff to make a heavy impasto (dark colouring). I do not know what I am doing in the painting. But I see and realize what I did after an introduction 'period." (Harrison \& Wood, 1992, p.610).
\end{abstract}

This new approach is based on experience that emerges as a result of interrogation of modern art. Traditional methods and materials such as paint, brush, painting process, pallet easel, familiar canvas pallet, workshop and their functions are abolished and a new function of applying materials through movements of the artist and his own existence produces the work of art. Pollock is distinguished from modern art perception in the following way; although Modern art is intellectually revolutionary period, it is quite traditionalist with respect to the methods of production and aesthetic values. Picasso's view of Cubist painting is seen as a milestone in terms of its content but is comprised of traditional pictorial factors.

The intellectual leap of Cubism in artistic content and Pollock's artistic expression which resembles a performance and the artist as the object of the work revolutionizes art and its habits onto a new plain. In the adventure of artistic expression, the artist becomes both the subject and object of the process.

\title{
CONCLUSION
}

Human culture and identity is formed by the conditions of the environment and nature it is harbored by. 'Line/drawing' -that does not exist in nature- is a unique tool in rendering thoughts and ideas. Humans, use this distinctive tool of expression to depict the nature they live in to actualize their own existence.

This paper examined the evolution of approaches in art education brought forward by Barbizon school in human-nature relationship by considering works of art produced. In this study, the new tendencies that divergence of Barbizon school took by distancing itself from the traditional Academic Art Education are addressed. Barbizon school's art education shows parallelism with the emergence of the individual and individualism that became apparent in society after the collapse of feudalism and monarchy. The Barbizon School's innovative approaches in rendering scenes of nature had created a different perception of nature for ensuing art movements.

Invention of photography forced Art education to search for new criteria in depicting nature. Barbizon school's departure from the traditional Academic understanding of art and aesthetic education, where scenes of every-day life and ordinary world came to be depicted in a 'realist' approach paved the road for Impressionism.

As a reaction to the outstanding achievement of photo camera's objective documentation of scenes of nature, Impressionists sought to find subjective perception and impressions of nature as subject matter. 
Impressionists inclined towards a different perception of existence and new ways of seeing while adhering to the naturalist tradition by focusing on the subjective emotions and perception which the changing daylight created on objects in nature. This approach leads to the loss of elements of mass, depth and distance that were far more important in earlier understandings of art.

Paul Cézanne who brings a new interpretation to painting as geometric shapes in lieu of the dissolution of mass, form and perspective due to subjective perception, creates a connection between Post-Impressionism and Cubism that would lay the foundation for Modern Art.

Cubist movement, takes Cézanne's approach of interpreting nature through geometric shapes to an abstract geometricism. In Cubist understanding, nature is not depicted as how it looks but how it is conceptually mapped in the mind of the artist. This approach brings a radical change to the ways of depicting nature since Renaissance, emancipating the artist from realist portrayal of nature.

The liberation from the realist depiction that Cubist movement realizes helps mass and form of objects to be actualised through different points of view projected onto the same surface. The new experience reached in Art, provides an artistic expression of nature without being confined to naturalist depiction of nature.

Modern Artist illustrates nature vividly and freely through mental, conceptual and intrinsic modes of seeing. Human exertion as a domination of the world accelerates with industrialisation, which in a way, corresponds to the prevalence over the projection of objects in nature with Modern Art.

This study considers the nature-art relationship and artistic expression process and form of Jackson Pollock's works, who accepts the experience of modern art's approach on expressing nature as a mental perception as a foundation for his artistic performance.

The awareness of this experience helps him to abandon the rules of methodology, form, consistence, beauty, composition and aesthetic values of his time. Pollock breaks away from the traditional ways of painting that was accepted as the statement of mental and emotional reflection.

The unconscious element of Pollock's performance eliminates artist's subjectivity to penetrate on the works. Pollock creates his paintings by dripping paint on his canvas surface in unconscious movements without any sketches or a detailed pre-planning and without the use of any tools. This style of painting formed by dripping paint does not directly comprise the artist's personality or identity on the surface of the work. The end product that does not incorporate the subjectivity of the artist becomes a side element and a bi-product.

Artist's movements and ritualistic dances are the tool, material, key element and the subject of his artistic expression. Pollock's experimental paintings give way to a manifestation of his transcendental existence in nature without directly depicting the nature he exists in.

By removing the elements of perception of nature, inner and mental effects, Pollock does not add any extra 'factor' to his paintings other than his own existence. This chain of relations, presents a revolutionary perspective on the works of art and nature. This approach of the artist that produces a self-confrontation, attributes a potential knowledge value to his works of art.

\section{REFERENCES}

Adnan, T. (1992). Dünya Sanat Tarihi. İstanbul: Remzi Kitabevi

Berger, J. (2011). The success and failure of Picasso. UK: Vintage.

Burke, P. (1969). The Renaissance sense of the past. London: Hodder Arnold.

Cunningham, A. (2000). Essential Impressionists. UK: Dempsey Parr.

Gombrich, E. H., \& Gombrich, E. H. (1995). The story of art (Vol. 12). London: Phaidon.

Harrison, C., \& Wood, P. (Eds.). (1992). Art in theory, 1900-1990: an anthology of changing ideas (Vol. 3). Oxford: Blackwell.

Heilbrun, F. (2009). Impressionism and Photography. History of Photography, 33, 1, 18-25. doi:10.1080/03087290802582889

Ismail, T. (2002). Sanat Ontolojisi. Istanbul: Inkılap Yay.

Jia, Q., Keheng, Z., \& Haiyang, Y.(2017). Art Design Education in the New Era Featured with the Integration of Arts and Motion Sensing Technology. EURASIA Journal of Mathematics Science and Technology Education, 13(8), 5883-5891. doi:10.12973/eurasia.2017.01037a

Lynton, N. (1980). The story of modern art. London: Phaidon Press.

Panofsky, E., Wood, C. S., \& Wood, C. (1991). Perspective as symbolic form (p. 31). New York: Zone books.

Picasso, P., \& Ashton, D. (1988). Picasso on art: A selection of views. Massachusetts, Cambridge: Da Capo Press. 
Shiner, L. (2001). The invention of art: A cultural history. Chicago: University of Chicago Press. Soykan, Ö. N. (2009). Sanat Sosyolojisi-Kuram ve Uygulama. Istanbul: Dönence Yayınları.

Todorov, T., Legros, R., \& Foucroulle, B. (2005). La naissance de l'individu dans l'art. France: Grasset.

Tunalı, İ. (2003). Felsefenin Işı̆̆ında Modern Resim (6. Basım). İstanbul: rh+ Yayınları.

\section{http://www.ejmste.com}

